\title{
Relationship Communication and Customer Satisfaction as Predictor of Customer Engagement
}

\author{
Hasnidar $^{1}$, Mahlia Muis ${ }^{2}$, Ria Mardiana ${ }^{3}$, Maat Pono ${ }^{4}, \mathrm{Jusri}^{5}$ \\ \{asnihasnidar@gmail.com¹,mahliamuis@yahoo.co.id ${ }^{2}$,riamard@unhas.ac.id ${ }^{3}$,maatpono@yahoo.com ${ }^{4}$, \\ jusrij@yahoo.com ${ }^{5}$ \} \\ STIE Makassar Maju, Makassar, Indonesia ${ }^{1}$ \\ Universtas Hasanuddin, Makassar, Indonesia-5
}

\begin{abstract}
Customer engagement reflects the level of customer involment related to the company's products, services, and activities. This study aims to analyze and explain the effect of relationship communication on Customer satisfaction and customer engagement. The research was conducted in five Islamic customer Banks in Makassar. The research used the survey method and purposive sampling technique with the total sample 250 respondents. The types of data used in the research were the quantitative data collected from the sources of the primary and secondary data. The data were then analyzed using regression analysis with SmartPLS technique. The research results proved that relationship communication has a positive and significant effect on customer satisfaction and customer engagement. The more effective communication implemented by the company, will encourage the higher level of customer engagement of Islamic banking customers.
\end{abstract}

Keywords: Relationship Communication, Customer Satisfaction, Customer Engagement and Islamic Banking

\section{Introduction}

The era of Islamic banking has begun with the enactment of Law No. 7 of 1992 concerning Banking which became the legal basis for the establishment of profit-sharing banks, but factually in 1991, Bank Muamalat Indonesia was established [1]. The potential for the development of Islamic banks in Indonesia is very high. Evidenced by Indonesia's population of 228,523,300 inhabitants, this number is the 4th largest number after the population of China, the United States and India. But Islamic image of prospective customers and customers of Islamic banks in Makassar is still low. The market share achievement of Islamic banks especially in Makassar is still below 5 percent and nationally it is still around 5 percent indicating that the views or perceptions of the Makassar people in particular towards the existence of Islamic banks are still very low. If departing from the population of Indonesia which is predominantly Muslim, it still lags far behind the State of Malaysia whose market share has reached 40-50 percent [2]. Naseer et al. (1999); Abdullah et al. (2012); Abduh, (2013) that public perception to choose Islamic banks for religious reasons is more important than profit reasons. While Bariah et al. [3]; Dewa dan Zakaria, [4]; Hamsani et al. [5] found that the community stated the use of Islamic banks is not due to religious values but rather the reasons for the benefits provided, location and others. Customers still have economic motives 
in choosing Islamic banks. The process of interaction of employees is very helpful in providing services to customers.

The concept of Islamic banks to build closeness with consumers is not only when consumers will conduct transactions but is intense in communication. Communication is a very important component in building long-term relationships both for potential customers and customers who have long established relationships with Islamic banking. Finne and Grönroos [6]. Reveal that a decrease in the value of a service or relationship will fail due to lack of good communication between the buyer and seller. To extend relationships with customers it is better to be able to communicate intensely, keep promises, provide timely and transparent and reliable information [7]. Many obstacles faced by Islamic banks include the lack of human resource competence in the field of Islamic banking. that there are a number of factors that have caused the market share of Islamic banking to not be reached between an inadequate understanding of the community regarding Islamic banking operations, limited quality of resources, lack of innovation in developing sharia-based products and lack of government support in developing Islamic banking [8],[9].

Islamic banks need to continue to increase the scale of their intensity towards consumers by utilizing existing loopholes to increase consumer engagement. If engagement is applied consistently, consumers will be more bound by Islamic banking. Anderson and Narus [10] that not only do communication in relation to marketing but how to instill trust in customers is the target of strengthening as a customer. So it not only has an impact on transactions but maintains a stable value of retention but also gives birth to consumers' commitment to Islamic banking and creates referral marketing.

Pansari and Kumar [11] revealed that customer engagement is a mechanism for adding customer value to Islamic banking, either through direct and or indirect contributions. Direct contributions consist of increasing transaction value and indirect contributions consist of referral incentives, customer social media conversations about brands, and customer feedback / suggestions provided to Islamic banking. The uniqueness of this behavior is that the customer is voluntary. Although customers do not generate direct revenue for Islamic banking, they have helped to strengthen the image of Islamic banking and influence other consumers' decisions for future purchases, thereby increasing profitability and business value in the long run.

This study extends previous research by examining empirically how communication affects satisfaction and customer engagement in B2C service relationships. This research is about marketing relations by developing and testing a Islamic banking communication model from a customer perspective. Previous research by Balaji et al. [12] which examines that communication can predict the sustainability of customer relations with banks in Malaysia. While Fierro's research, 2014 revealed the importance of building relationships in developing customer engagement. Therefore, this study will examine the importance of communication in predicting customer engagement in the perspective of Islamic banking customers.

\subsection{Theoretical Background}

Relationship marketing is an effort to get to know consumers better, so companies can meet their needs and wants in the long run [13]. Serving customers does not stop at the level of consumers feeling satisfied. Satisfied consumers do not necessarily become loyal customers. Consumers who said they were satisfied with the quality of products or services as well as pe the services of the company, could easily move on products and services of other 
companies that have assessed the quality of the same or has the quality a little better. by him that need a better understanding of the needs of and customer expectations.

Mehrabian and Russell's [14] Stimulus-Organism-Response (S-OR) Paradigm is one of the earliest frameworks developed to be investigated for the influence of the atmosphere on customer behavior and it continues to be widely used. Given that studies of customer engagement have shown beneficial results, it is necessary to determine stimulus variables (S) that affect the organism $(\mathrm{O})$ and, in turn, bring changes in response $(\mathrm{R})$ to service settings. Stimulus refers to environmental factors anything else that gave rise to internal reactions of individuals to the environment. In service settings, such as hotels, mood elements act as stimuli (S) for customer responses. Respect to organisms $(\mathrm{O})$, the original model states that customers experience three types of emotional states: pleasure; passion, and dominance. However, in this study, only the emotional state of customer satisfaction was investigated. There is evidence that organisms $(\mathrm{O})$ can influence the results of behavioral responses $(\mathrm{R})$ : [15].

A number of studies have emphasized the importance of communication and its impact on changing customer attitudes and on certain product brands. Elaborating models for processing information emphasizes the ability of communication to process and motivate the process of communication messages. In stimulating consumers, communication messages may differ in some contests, where there are informative or emotional ones, and creative design and communication strategies [16].

Communication is the ability to provide timely and reliable information. Communication as an interactive dialogue between a company and its customers that takes place during the pre-sales, sales, consumption and post-consumption stages [10]. Communication in relation to marketing means providing reliable information, providing information when delivery problems occur, providing information about quality problems and being able to fulfill promises is the communicator's task to build awareness, build consumer preferences by promoting quality, value, performance and other features, encouraging buyers who are interested in making a purchase decision [7].

Customers always want the creation of effective communication with the company, communication or interaction of employees in terms of providing information, providing solutions when there is satisfaction with consumers will provide satisfaction to customers and are willing to continue the relationship with the company. This relationship is not just to make a purchase or transaction will but customers will be willing to be a word of mouth and will refer to friends and family. This relationship is called customer engagement. Vivek et al. [17] shows that the theoretical root of the concept of customer engagement lies in the relationship marketing domain. In domain of relationship marketing, companies focus on customers such as consumer communities and organizational value creation. Previously, the main objective of relationship marketing was to build a long-term relationship with the company, the relationship between the customer and the company was limited to purchases and ensure longterm loyalty [13]. However, this has evolved along with developments in the market based on needs and the interests of consumers, where consumers always want to connect with the company, through social media, interact with users of other products and make evaluations of company performance [11].

Customer engagement combines transactional and non-transactional behavior (word of mouth, blogging or referrals, and co-creation), which can have a strong impact on company results, even if not directly [18],[19]. The relationship between the customer and the company develops only if the customer is satisfied with the company and also emotionally connected with the company [11]. In other words, for customer engagement to exist, customers must 
have a satisfied and emotionally connected relationship with the company. However, this relationship develops over time and varies and based on customer and company experience. This experience is only positive if the initial purchases made by customers meet customer expectations.

In relationship marketing, communication not only serves as a persuasive service but how to create Bidirectional Communication is related to providing information, listening and answering, which requires interaction in the form of two-way communication [6]. The concept of this research is a multidimensional communication relationship consisting of cognitive, affective, and behavioral components. Customers value company communication in terms of clarity, pleasure, responsiveness, and language.

According to Palmatier et al. [20] communication improves the quality of relationships and builds stronger relationships. This is supported by other research which found that intensive communication occurs in close relationships [21]. Although it has been found that communication styles can be very different in focus in Asia and the West [22], communication has been identified as one of the conditions that must be met by exchange partners for each exchange of relations (regardless of culture) [23].

In the world of banking, communication means as done through letters, mail, interactions on other websites and machines related to interactions and even personal interactions with personnel who provide services after, before and during transactions. Ball et al. [24], revealed that communication can be done through written communication such as correspondence, e-mail, web sites, or other interactions such as direct communication with company employees before, during, and after making transactions.

Eftimie et al. [25], found that communication not only has an impact on customer satisfaction but has an impact on employee satisfaction and contributes to the stability and sustainability of the company. Communication can play a major role in managing customer relationships so that customer satisfaction is achieved [26], [27], [28]. The research results of Cambra-Fierro et al. [29] found that frontline employees are able to engaged customers as long as they are able to provide services by communicating well in the event of complaints by customers. Effective communication can encourage the creation of transactional behavior (repurchases, loyalty) and non-transactional behavior (commitment of word of mouth recommendations and customer to customer) [17], [30]

The research hypotheses proposed and tested in this study have their basis in the SOR model [14], Based on the SOR (Stimulus-Organism-Response) model propose that corporate communication (ie stimulus) influences customer cognitive and affective states of satisfaction (organism). This internal situation affects the commitment and customer loyalty to the company (response). The research model is shown in Figure 1. The hypothesis we propose is as follows:

H1: Relationship communication has a significant impact on customer engagement

$\mathrm{H} 2$ : Relationship communication has a significant impact on customer engagement

H3: Customer engagement has a significant impact on customer engagement 


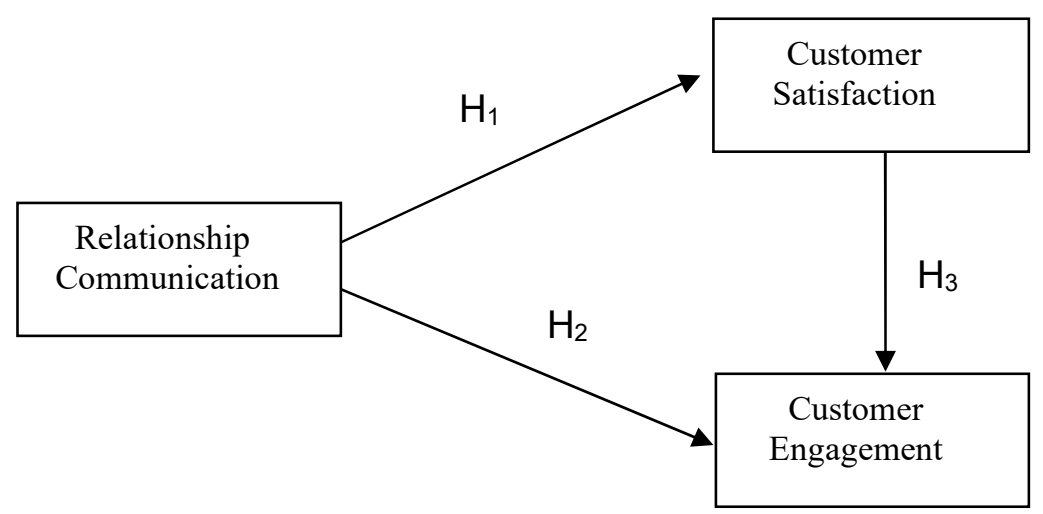

Fig.1. Hypothetical Research Model

\section{Research Methodology}

We use a sample of 250 Islamic banking customers using accidental sampling techniques. The questionnaire was distributed by filling in using the Likert scale of points 1 5 , where the number 1 shows strongly disagree until point 5 which is strongly agreed. Data analysis techniques using analysis of Structural Equation Model (SEM) Partial Least Squares (PLS) 3.

\section{Result and Discussion}

Respondents were dominated by respondents with ages 15-30 totaling 152 respondents or 65 percent, respondents male sex numbered 121 respondents or 52 percent and women 110 respondents or 48 percent. The biggest composition is having the status of married as many as 140 people or 69 percent . Of the types of work, employees are the most respondents, as many as 165 respondents or 71 percent. There is a tendency that Islamic bank customers are employees, where employees desperately need fast and appropriate service quality. Respondents with a Bachelor degree (S1) had the largest percentage of 125 respondents or 54 percent. Characteristics of respondents based on being a Islamic bank customer for a period of less than 3 years amounted to 106 respondents or 46 percent and customers who had established relationships with banks around 3-5 years as much as 78 respondents or 34 percent. Over 5 years there are 47 respondents or 20 percent .

The average value for communication variables 4.19 with good categories. The satisfaction variable has an average value of 4.21 and customer engagement with an average value of 4.19. The structural model was analyzed using smart PLS 3. To test it by calculating the path coefficient and the $t$ value of the parameters obtained using the boostrap technique. This measurement confirms the accuracy and stability of estimates. Table 1 shows 
the importance of the structural path to see the hypotheses proposed in the model accepted or rejected.

Table 1. Crossloading within Variable

\begin{tabular}{|c|c|c|c|}
\hline Variables / Indicators & Average & $\begin{array}{l}\text { Cross } \\
\text { Loading }\end{array}$ & $\begin{array}{c}\mathrm{AVE}> \\
0.5\end{array}$ \\
\hline \multicolumn{4}{|l|}{ Relationship communication } \\
\hline $\begin{array}{l}\text { 1. Employee of Islamic banking are clear in } \\
\text { communicating because customers don't question } \\
\text { anymore and don't make complaints }\end{array}$ & 4.12 & 0.669 & \multirow{4}{*}{0.50} \\
\hline \multirow{3}{*}{$\begin{array}{l}\text { 2. Communicating with Islamic bankers is very } \\
\text { pleasant because the duration of communication } \\
\text { does not long } \\
\text { 3. Islamic bankers quickly respond if there are } \\
\text { questions and complaints from customers } \\
\text { 4. Islamic banks always use positive language in } \\
\text { providing services to their customers. }\end{array}$} & 4.09 & 0.730 & \\
\hline & 4.05 & 0.739 & \\
\hline & 4.12 & 0.700 & \\
\hline \multicolumn{3}{|l|}{ Customer satisfaction } & \multirow{4}{*}{0.56} \\
\hline 1. I am very satisfied with all Islamic bank services & 4.16 & 0.760 & \\
\hline $\begin{array}{l}\text { 2. In general, I have a good opinion about Islamic } \\
\text { banks }\end{array}$ & 4.28 & 0.812 & \\
\hline $\begin{array}{l}\text { 3. Satisfied with all the Islamic bank services, I will } \\
\text { increase my transactions }\end{array}$ & 4.19 & 0.672 & \\
\hline \multicolumn{3}{|l|}{ Customer engagement } & \multirow{6}{*}{0.53} \\
\hline $\begin{array}{l}\text { 1. I will not switch to another bank / conventional } \\
\text { service }\end{array}$ & 4.22 & 0.748 & \\
\hline 2. I and Islamic banking are committed to & 4.15 & 0.757 & \\
\hline $\begin{array}{l}\text { maintaining relationships because of one faith and } \\
\text { based on piety }\end{array}$ & 4.18 & 0.682 & \\
\hline $\begin{array}{l}\text { 3. I will speak positively about Islamic banks to } \\
\text { family and friends }\end{array}$ & \multirow{2}{*}{4.21} & \multirow{2}{*}{0.733} & \\
\hline $\begin{array}{l}\text { 4. I will participate by giving advice and opinions } \\
\text { on the development of Islamic banks }\end{array}$ & & & \\
\hline
\end{tabular}

Source: Processed Data from SmartPLS (2018)

Table 1 shows that the indicators for each exogenous and endogenous variable generally have good loading factor values, because the average is above 0,70 . This indicates that the indicators used to measure each construct meet convergent validity. In addition, the AVE value indicates that all variables have $\mathrm{AVE}>0.50$, thus it can be concluded that evaluation of model measurements has good discriminant validity.

Table 2. Total Effect

\begin{tabular}{|c|c|c|c|c|c|c|}
\hline Latent Vaiable & $\begin{array}{c}\text { Composite } \\
\text { Reliability } \\
\rho c \geq 0.7\end{array}$ & $\begin{array}{c}\mathrm{R} \\
\text { Square }\end{array}$ & $\begin{array}{l}\text { Cronbachs } \\
\text { Alpha } \\
\text { CA }>0.7\end{array}$ & $\begin{array}{l}\text { Indi- } \\
\text { cator }\end{array}$ & $\begin{array}{l}\text { Redun } \\
\text { dancy }\end{array}$ & $\begin{array}{r}\text { Outer } \\
\text { Model } \\
\text { Statistics }\end{array}$ \\
\hline
\end{tabular}




\begin{tabular}{|c|c|c|c|c|c|c|}
\hline Relat. Communication & 0.802 & & 0.672 & Reliable & & 4.501 \\
\hline Customer Satisfaction & 0.793 & 0.409 & 0.612 & Reliable & 0.006 & 17.169 \\
\hline Customer Engagement & 0.821 & 0.488 & 0.7100 & Reliable & 0.001 & 6.339 \\
\hline
\end{tabular}

Source: Processed Data from SmartPLS (2018)

Reliability test uses cu t-off composite reliability $>0.70$ which is a good reliability requirement. When viewed from the composite reliability output all variables are reliable because they have a composite reliability (CR) value above 0.70 . The reliability test in Table 2 can also be seen from the Cronbach Alpha value $>0.5$ which is considered good. all variables have met the good reliability because all of them have Cronbach Alpha more than 0.50 .

Table 3. Results Of The Structural Model

\begin{tabular}{lc}
\hline Relations between variables & $\begin{array}{l}\text { Coefficient } \\
(T \text { value; bootstrap }) \\
(N=231)\end{array}$ \\
\hline $\mathrm{H}_{1}:$ Relationship Communication $\rightarrow$ Customer satisfaction & 0.000 \\
$\mathrm{H}_{2}$ : Relationship Communication $\rightarrow$ Customer engagement & 0.000 \\
$\mathrm{H}_{3}:$ Customer satisfaction $\rightarrow$ Customer engagement & 0.000 \\
\hline
\end{tabular}

Source: Processed Data for SmartPLS

This condition can also be seen in Figure 2 or the following bootstraping test model.

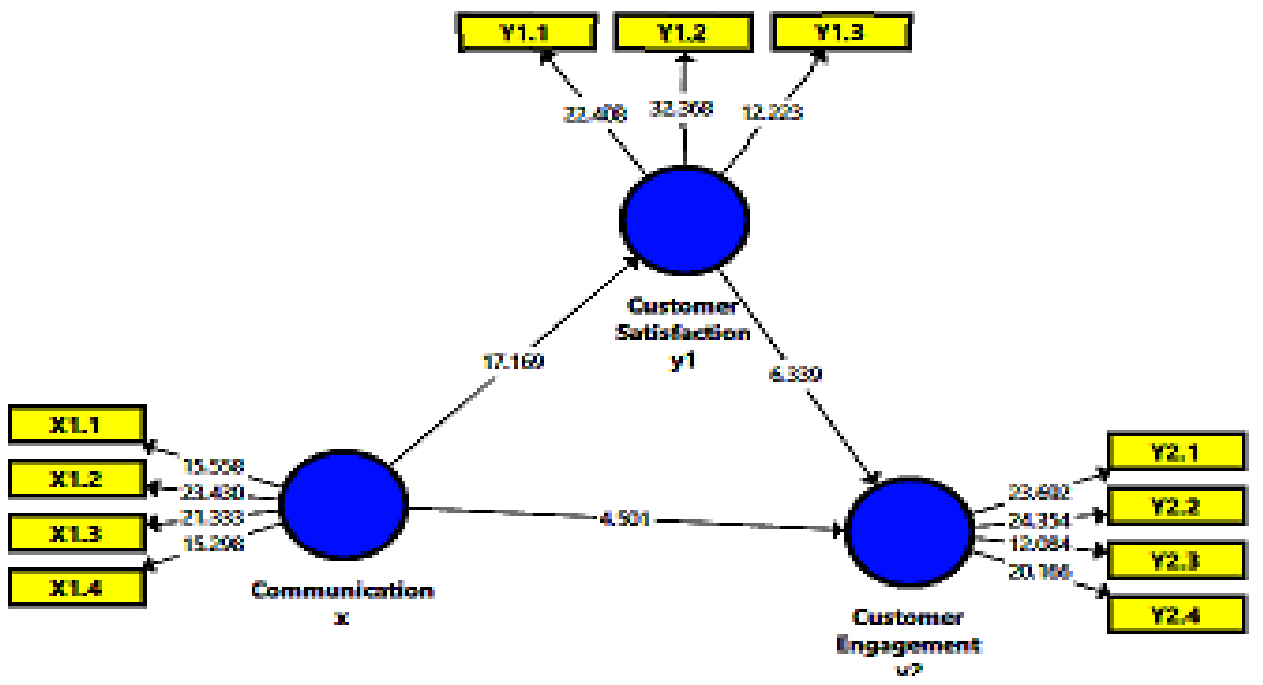

Fig. 2. Bootstraping

The significance test of the model using the bootstrapping technique results can be seen in Table 3. The results show the following $p$ values:

1. Relationship Communication has a significant effect on customer satisfaction with a factor loading coefficient of 17.160 and a $\mathrm{p}$ value of 0.000 means that the higher the 
communication. it will increase customer satisfaction of Islamic bank customers in Makassar.

2. Relationship Communication has a significant effect on customer engagement with a factor loading coefficient of 4.501 and a $p$ value of 0.000 means that the higher employee competence will increase customer engagement of Islamic bank customers in Makassar.

3. Customer satisfaction has a significant effect on customer engagement with a factor loading coefficient of 6.339 and a $p$ value of 0.000 means that the higher customer satisfaction will increase customer engagement of Islamic bank customers in Makassar.

\subsection{Discussion}

The purpose of this study is how the influence of communication or employee interaction can improve customer engagement. Descriptive analysis results show that relationship communication in Islamic banking Makassar is in the good / important category. Therefore. to increase customer engagement. one of the factors that needs attention to improve its effectiveness is communication. The basic theory of service recovery proposed by Zeithamal [31]. That basically. a communication is carried out to convey something. More than that. in some conditions communication is used to change the perspective and attitude of others towards something. Changes in attitude will occur more quickly by touching one's feelings and hearts. and coupled with a rational argument. Bleek and Ernst [32] argue that communication must be done well because the relationship will fail without good communication between buyers and sellers.

Clarity in receiving information about the benefits and advantages of Islamic products with a short duration of communication. customers are treated fairly and easily responded to. and understanding the language used is an indicator that customers can be bound to Islamic banking. Roy et al. [33] revealed that to motivate customers to engage in a company and be able to develop markets. service providers need to treat them fairly. build cognitive and affective trust and understand how they create use value [33]. The results of this study are also supported by Lassar [12] that communication is very influential on the sustainability of consumers in relation to B2C services. This supports the SOR model theory [14]. that corporate communication affects the cognitive and affective conditions of customers. which in turn affects commitment to the company.

When the company receives various complaints from customers. employees show an interest in solving problems and providing fair solutions to customers. so as to create customer satisfaction. The actions taken by employees and their responses to customer requests is one of the most effective communication tools. When customers feel cared for. get a quick response from every question or complaint. as well as fulfilled all their desires. then makes the customer committed to remain in the company. Customers will promote Islamic banks to friends and family and will provide the best input for Islamic banks because of the good communication received from employees of Islamic banks. This is supported by research by Voyles and Mohebi. (2015) that an equally important factor affecting customer engagement is intensive communication. primarily answering customer questions. in addition. research conducted by Cambra-Fierro et al. [34] found that employees are able to manage customers as long as they are able to provide services by communicating well in case of complaints by customers. This is in accordance with the theory of Social Exchange Theory put forward by John Thibaut and Harold Kelley (1959) states that each individual voluntarily enters and lives in a relationship only as long as the relationship is satisfactory in terms of respect and 
sacrifice. Effective communication can encourage the creation of transactional behavior (repurchase. loyalty) and non-transactional behavior (commitment. word of mouth recommendations and customer to customer) [17], [30].

\section{Conclusion}

Employees play an important role in determining the continuity of relationships between customers and banks. Clarity in receiving information. not long duration of communication. as well as being quickly responded to and given solutions are indicators that customers can be engage to Islamic banking. The more effective communication implemented by the company. will encourage the higher level of customer engagement of Islamic banking customers.

\subsection{Research limitations}

The customer engagement variable is a new variable and there are still few who do research on that variable. Therefore there are still few references that support the results of this study. This research is also still limited to companies engaged in services.

\section{References}

[1] DetikFinance, "Sejarah Berdirinya Bank Syariah di Indonesia," 2018. [Online]. Available: https://finance.detik.com/moneter/d-3894544/sejarah-berdirinya-bank-syariah-di-indonesia.

[2] “detik 2017." [Online]. Available: http://www.dream.co.id/dinar/bi-akui-penetrasi-perbankansyariah-ri-masih-rendah-1510275.html.

[3] Bariah, N., Hubeis, M., and Hafidhuddin, D.: "The determinants of Islamic banking human resource performance: bank syariah mandiri Indonesia," Int. J. Inf. Technol. Bus. Manag., vol. 40, no. 1, pp. 98-105 (2015)

[4] Dewa, N., and Zakaria, S.: "Training and development of human capital in Islamic banking industry," J. Islam. Econ. Bank. Financ., vol. 8, no. 1, pp. 95-108 (2012)

[5] Sule, E. T., and Kaltum, U.: "Islamic Perspective on Competence to Increasing Organizational Citizenship Behavior (OCB) with Knowledge Sharing Behavior as a Moderation Variable of Sharia Bank Employees in the Bangka Belitung Islands Province," Acad. Strateg. Manag. J (2017)

[6] Finne, A. and Grönroos, C.: "Rethinking marketing communication: From integrated marketing communication to relationship communication," J. Mark. Commun., vol. 15, no. 2-3, pp. 179-195 (2009)

[7] Ndubisi, N. O.: "Relationship marketing and customer loyalty," Mark. Intell. Plan. (2007)

[8] Lone, F. A., Aldawood, E., and Bhat, U.: "Comparative analysis of customer satisfaction towards Islamic and conventional banking: an empirical study from Saudi Arabia," Int. Rev. Manag. Mark., vol. 7, no. 1, pp. 273-280 (2017)

[9] Reni, A., and Ahmad, N. H: "Application of theory reasoned action in intention to use Islamic banking in Indonesia," Al-Iqtishad J. Ilmu Ekon. Syariah, vol. 8, no. 1, pp. 137-148 (2016)

[10] Anderson, J. C., and Narus, J. A.: "A model of distributor firm and manufacturer firm working partnerships," J. Mark., vol. 54, no. 1, pp. 42-58 (1990)

[11] Pansari, A., and Kumar, V.: "Customer engagement: the construct, antecedents, and consequences," J. Acad. Mark. Sci., vol. 45, no. 3, pp. 294-311 (2017)

[12] Lassar, W. M., Roy, S., and Makam, S. B.: "Relationship communication and relationship quality as predictors of relationship continuity," in Rediscovering the Essentiality of Marketing, Springer, pp. 745-746 (2016) 
[13] Berry, L. L.: "Relationship marketing of services—growing interest, emerging perspectives," $J$. Acad. Mark. Sci., vol. 23, no. 4, pp. 236-245 (1995)

[14] Mehrabian, A., and Russell, J. A.: An approach to environmental psychology. the MIT Press (1974)

[15] Robert, D., and John, R.: "Store atmosphere: an environmental psychology approach," J. Retail., vol. 58, no. 1, pp. 34-57 (1982)

[16] Brengman, M., Geuens, M., and De Pelsmacker, P.: "The impact of consumer characteristics and campaign related factors on brand confusion in print advertising," J. Mark. Commun., vol. 7, no. 4, pp. 231-243 (2001)

[17] Vivek, S. D., Beatty, S. E., and Morgan, R. M.: "Customer engagement: Exploring customer relationships beyond purchase," J. Mark. theory Pract., vol. 20, no. 2, pp. 122-146 (2012)

[18] Kumar, V., Aksoy, L., Donkers, B., Venkatesan, R., Wiesel, T., and Tillmanns, S.: "Undervalued or overvalued customers: capturing total customer engagement value," J. Serv. Res., vol. 13, no. 3, pp. 297-310 (2010)

[19] Van Doorn, J. et al:: "Customer engagement behavior: Theoretical foundations and research directions,” J. Serv. Res., vol. 13, no. 3, pp. 253-266 (2010)

[20] Palmatier, R. W., Dant, R. P., Grewal, D., and Evans, K. R.: "Factors influencing the effectiveness of relationship marketing: A meta-analysis," J. Mark., vol. 70, no. 4, pp. 136-153 (2006)

[21] Holden, M. T., and Otoole, T.: "Affirming communication's primary role in a manufacturer-retailer context," J. Mark. Manag., vol. 20, no. 9-10, pp. 1047-1073 (2004)

[22] Yum, J. O.: "The impact of Confucianism on interpersonal relationships and communication patterns in East Asia," Commun. Monogr., vol. 55, no. 4, pp. 374-388 (1988)

[23] Kotler, P.: "Manajemen Pemasaran, Jilid 1 dan 2, Jakarta: PT," Indeks Kelompok Gramedia (2005)

[24] Ball, D., Coelho, P. S., and Machás, A.: "The role of communication and trust in explaining customer loyalty," Eur. J. Mark. (2004)

[25] Eftimie, M., and Moldovan, R. G.: "The Communication'Impact on the Customer Satisfaction Level. Case Study.”(2016)

[26] Senguo, R. A., Xixiang, S., and Kilango, N. C.: "Marketing Communication Based on Customer Satisfaction and Loyalty: Zantel Tanzania," Int. J. Innov. Manag. Technol., vol. 8, no. 4, pp. 284 288 (2017)

[27] Al-Hersh, A. M., and Saaty, A. S.: "The impact of customer relationship marketing on customer satisfaction of the Arab bank services," Int. J. Acad. Res. Bus. Soc. Sci., vol. 4, no. 5, p. 67 (2014)

[28] Ndubisi, N. O., and Wah, C. K.: "Factorial and discriminant analyses of the underpinnings of relationship marketing and customer satisfaction," Int. J. bank Mark. (2005)

[29] Cambra-Fierro, J., Melero-Polo, I., and Vázquez-Carrasco, R.: "The role of frontline employees in customer engagement," Rev. Española Investig. Mark. ESIC, vol. 18, no. 2, pp. 67-77 (2014)

[30] Patterson, P., Yu, T., and De Ruyter, K.: "Understanding customer engagement in services," in Advancing theory, maintaining relevance, proceedings of ANZMAC 2006 conference, Brisbane, pp. 4-6 (2006)

[31] Zeithaml, V. A.: "Consumer perceptions of price, quality, and value: a means-end model and synthesis of evidence," J. Mark., vol. 52, no. 3, pp. 2-22 (1988)

[32] Bleeke, J. and Ernst, D.: "Is your strategic alliance really a sale?," Strateg. Crit. Perspect. Bus. Manag., vol. 4, no. 4 (2002)

[33] Roy, S. K., Balaji, M. S., Soutar, G., Lassar, W. M., and Roy, R.: "Customer engagement behavior in individualistic and collectivistic markets," J. Bus. Res., vol. 86, pp. 281-290 (2018)

[34] Cambra-Fierro, J. and Melero-Polo, I.: "Complaint-handling as antecedent of customer engagement: do consumer characteristics matter?," Mark. Intell. Plan. (2017) 